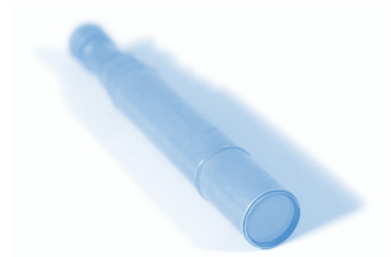

Karen Moss

Centre for Effective

Learning in Science

Clifton Lane

Nottingham

NG11 8NS

karen.moss@ntu.ac.uk

\title{
What is effective learning in science? Impact and outcome from a CETL
}

\begin{abstract}
What is it like to have HEFCE funding and the opportunity to spend it developing good practice in the learning and teaching of science for both higher education and school sectors? In this article we describe how CETL funding at CELS is being used to develop staff, engage students and promote interest in science amongst over 21,000 young people in the East Midlands. We report on how staff were enabled to develop new resources for the teaching of science from undergraduate to Masters level as well as pioneering innovative outreach activities for schools (for students from 5 years old upwards) through our innovative sabbatical scheme for staff - which also supported early career academics in gaining full lecturing posts. CELS' projects cover a wide range of science - both the traditional and interdisciplinary. Examples include work on troublesome knowledge in chemistry, forensic science and physics, new approaches to assessment, e-learning materials for protein purification and biochemistry, new experiments in green chemistry, physics for forensics and astronomy projects for schools. However, this is also a story of pushing boundaries where effective collaborations across subject and institutional boundaries allowed new developments in outreach e.g. at the science-art interface which led to critically acclaimed theatre productions on science.
\end{abstract}

\section{Introducing CELS - a CETL}

The Centre for Effective Learning in Science (CELS) at Nottingham Trent University is a HEFCE funded Centre for Excellence in Teaching \& Learning - a CETL. What are CETLs and why did HEFCE invest over £300 million in them? HEFCE said:

We envisage that CETLs will sustain and stimulate further excellent practice through teaching that is informed by scholarly reflection, developed through innovative and adventurous thinking, extended to learning in new contexts, and (reach a wider audience) through active dissemination of good practice'. (HEFCE Invitation to Bid 2004/05, paragraph 16)

In this review I will demonstrate how we are seeking to convert that vision into reality.

CELS is one of 74 CETLs and one of six with a specific science focus. We cover both traditional core sciences (biology, chemistry \& physics) as well as the newer interdisciplinary sciences (forensic and sports science). CELS aims to:

- teach science in HE more effectively and

- inspire the next generation of scientists

Our spectrum of CETL activities includes developing forms of teaching (online learning); ways of conceptualising and supporting student learning (practical work, simulations); influencing the curriculum through work placements in schools; improving assessment; and effectively encouraging young people to aspire to Higher Education.

\section{Investing in people}

Staff are both the major resource and cost in higher education. First and foremost, our HEFCE funding was therefore an opportunity to invest in people - staff, students and the wider community - allowing them to develop their ideas and potential. How did we do this?

a) Developing staff - the TIPS TOPS scheme

For academic staff the CELS sabbatical scheme was created. It is based on secondment of academic staff for up to one year, usually on a part-time basis, (similar to a 'research sabbatical' model). Seconded staff carry out projects in one of two areas either with the Team for Integrative Projects in Science (TIPS) or the Team for Outreach 
Projects (TOPS). The role of TIPS TOPS is to deliver the key CELS objectives as well as local learning and teaching strategies. Topics undertaken cover all subject areas in the School of Science \& Technology.

The TIPS TOPS scheme also seeks to help staff obtain maximum benefits from their sabbaticals e.g. in collecting evidence for claims for promotion under university reward and recognition policies. Accordingly, TIPS TOPS staff are supported by a programme of activities to help them develop their approach to scholarship and reflective practice. One objective of this support was to enhance staff engagement with evaluation of their projects as well as active dissemination of their outcomes. HEFCE requires robust evaluation and dissemination strategies from all its CETLS .

An emerging theme is that staff, who are expert researchers in their own field, may be uncertain of

how to publish in science education. We offer support by building in action learning sets and staged internal dissemination activities as well as opportunities to attend development events, present at conferences and write papers. Evaluation of the TIPS TOPS scheme itself, over the three years it has operated, shows that whilst there is room for improvement, colleagues did attach most value to having time and space to reflect on their teaching and to develop their perceptions of student learning. We are currently engaged on a comparative research study of how this model of staff development compares to other schemes operating in the university ${ }^{1}$.

One observation from this and other experiences of evaluating science education projects, is that many proposed evaluation strategies are superficial and limited to a version of a 'happy sheet' e.g. "Evaluation will be via an electronic satisfaction questionnaire for the 1st cohort". However, the challenge for science education projects is to go beyond this and look instead at what measurable impacts there have been on learning or on other staff - i.e. getting people to consider questions such as "How will you know if you've been successful at improving learning?" "What baseline data do you need to gather before you start your project?" "What is an appropriate methodology?" Areas to consider can include improved assessment scores and changes in student learning practices.(See also section on effective learning below.)

b) CELS lecturers - career development and cover for TIPS TOPS

Frequently staff awarded a teaching and learning development project are expected to "buy themselves out of teaching'. This presents practical issues such as identifying someone to cover teaching. Such approaches do not usually support relief from associated assessment and administrative demands. To address these sorts of issues, we created fixed term three year appointments - the CELS Lectureships- as career development posts for aspiring lecturers. Our seven CELS lecturers undertake a full spectrum of lecturing duties, administrative duties, gain a full range of teaching experiences as well as joining an existing research team. They are offered places on the HEA accredited PGCertHE programme for new university lecturing staff. Going beyond providing cover for colleagues to undertake sabbaticals, CELS lecturers have themselves been innovative teachers - with contributions including new teaching resources and new activities to support outreach work, e.g. a Forensic Microbiology master class. This work contributed to a recent article on Bioscience Outreach at NTU for Microbiology Today ${ }^{2}$. The validity of approach as career development was demonstrated when two CELS lecturers successfully achieved full time lecturing positions after a full competitive appointment processes.

\section{c) Students}

We set out to improve the quality of the student learning experience by delivering more effective and innovative teaching materials and approaches, enhancing student employability and creating new learning environments through our new facilities. Much of this work has been through TIPS TOPS projects, other developments include:

\section{Enhancing Student Employability} A credit-rated, school-based, work experience placement (based on the successful national Undergraduate Ambassadors Scheme (UAS), see web links) was validated as a Level 3, 20 credit point option module on a number undergraduate programmes in science and technology. Communicating Science and Technology module was warmly welcomed by student representatives when it was introduced, [NB UAS scheme was new to NTU]. The module had grown from 8 students in its first year to 20 students in 2008-9. Several students have since trained as teachers. Students are trained, CRB checked and placed in a school for twelve halfdays. The idea is to improve the science experience of school pupils. Students taking the module state that the experience has improved their communication and presentation skills, their confidence and time management skills.

\section{Student projects}

We feel that it is important to engage students themselves with the research informed teaching agenda by carrying out research into learning. Projects have included designing, developing, delivering and evaluating resources for schools such as "A Forensic Kit in a Kase for Key Stage 3"; "A GCSE biology revision web site"; "A Forensic Science web site for Key Stage 4"; "PowerPoint revision resources with Flash animations for KS4 science"; and "Revision guides for new A2 chemistry programmes". They have also looked at learning 
issues in HE e.g. "investigating knowledge gaps and designing flexible learning materials for first year chemists".

What do we mean by effective and can we measure it? Having labelled ourselves as a Centre for Effective Learning one question to be asked is how do we know if we are 'effective'? Working with specialists and an external evaluator we evaluate at all levels - from individuals and a self-reflective approach through to an independent, external evaluator. Themes for evaluation have included:

- How successful are we at raising aspirations and how do we measure this?

- What is the quality of the student learning experience?

- What has the impact been on staff?

- Has the CETL affected a change on the university's systems and processes?

- Are the developments and lessons learned transferable across the sector?

Evaluation in these terms could be seen merely as 'jumping through hoops'. However, when meeting colleagues a common challenge is "Given all the money you've had - what impact are you having?" So what is impact when applied to CETLs?

Starting with dictionary and scientific definitions of impact ${ }^{3,4}$ reveals the following:

'The strong effect exerted by one person or thing on another';

or

'A force, also known as impulsive force, which acts only during a short time interval but which is sufficiently large to cause an appreciable change in the momentum of the system on which it acts.'
Wainwright's review ${ }^{5}$ of models and approaches (arising from studies in the social and voluntary sector) outlines some key concepts relating to impact measurement which offer some very useful pointers. In Measuring Impact: A Guide to Resources Wainwright ${ }^{5}$ states:

Impact is a widely used but rarely defined term in evaluation literature. Everyone wants to know how to measure their organisation's impact but without knowing quite what they mean by the term

Using Wainwright's approach it appears that what many people are actually referring to when talking about Impact are instead the more easily obtained metrics Wainwright defines as activities, outputs and/or outcomes (Table 1).

Examples of what Wainwright defines by each of these terms is given below:

Inputs are the resources that contribute to a programme or activity, including income, staff, volunteers and equipment.

Activities are what an organisation does with its inputs in order to achieve its mission.

Outputs are countable units, and are the direct products of a programme or organisation's activities. They could be classes taught, training courses delivered or people attending workshops. In themselves they are not the objectives of the organisation.

Outcomes are the benefits or changes for intended beneficiaries. They tend to be less tangible and therefore less countable than outputs. Outcomes are usually planned and are therefore set out in an organisation's objectives.

Impact is all changes resulting from an activity, project or organisation. It includes intended as well as unintended, negative as well as positive, and longterm as well as short-term effects.

\begin{tabular}{|c|c|c|}
\hline Concept & Definition & Examples in a CETL context \\
\hline Inputs & Resources invested in the CETL & income, staff and equipment \\
\hline Activities & $\begin{array}{l}\text { What we do with our inputs to achieve our } \\
\text { goals }\end{array}$ & $\begin{array}{l}\text { training, research projects, learning } \\
\text { developments, building learning spaces }\end{array}$ \\
\hline Outputs & $\begin{array}{l}\text { Tangible/countable products of a CETL's } \\
\text { activities }\end{array}$ & $\begin{array}{l}\text { sessions held, papers written, space } \\
\text { utilised, promotion schemes, student } \\
\text { learning interactions }\end{array}$ \\
\hline Outcomes & $\begin{array}{l}\text { Benefits/ changes to people from the ac- } \\
\text { tivity. Usually longer term and based on } \\
\text { CETL objectives }\end{array}$ & $\begin{array}{l}\text { improved student learning, raising } \\
\text { achievement, staff promotions, institu- } \\
\text { tional change }\end{array}$ \\
\hline Impact & $\begin{array}{l}\text { All change resulting from a CETL- in- } \\
\text { cludes: intended and unintended effects; } \\
\text { negative and\& positive; long-term and } \\
\text { short-term effects }\end{array}$ & $\begin{array}{l}\text { regional partnerships, interdisciplinary } \\
\text { projects, sustainability and embedding } \\
\text { of core ideals }\end{array}$ \\
\hline
\end{tabular}


I have interpreted the above definitions to fit the CETL initiative, noting that Outputs are about effort whilst Impact is about change. The results are shown in Table 1, which has formed the basis of workshops on Impact for the CETL community ${ }^{6}$. It is worth considering such concepts for any educational project.
- $\quad$ Supporting student learning - e.g. Student Ambassador \& Mentoring Scheme; A New Approach to teaching Programming

b) Investigating misconceptions Investigating how science concepts are understood, or misunderstood, is one of our Alternatively Boyd's approach in the New Economics Foundation (nef) publication Measuring Social Impact ${ }^{7}$, defines impact as

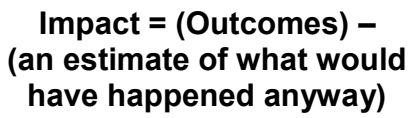

Boyd states that

Outputs are the direct

result of your business

objective or programme goal. So for example, 25 people learned new computer skills as a result of a training programme. An outcome is a change that has occurred over the longer term....So perhaps 2 of 20 programmers would have found jobs on their own. That means that the

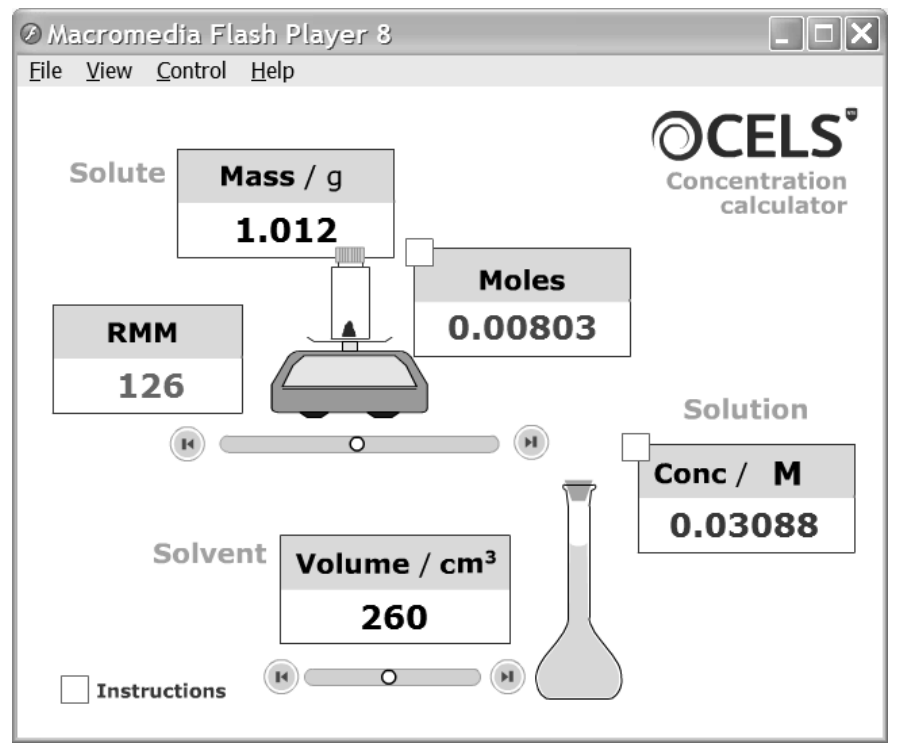

Figure 1: The Mole Calculator key areas of investigation at CELS and has involved student focus groups, questionnaires and diagnostic testing, carried out with first year students in chemistry, physics, forensic science and sport. Initial findings of this work and its overview of areas such as Threshold Concepts and Troublesome Knowledge were presented at the Science Learning and Teaching Conference and Variety in Chemistry Education in $2007^{8}$.

c) Interactive learning materials

One of our keys objectives is innovation in the teaching of scientific concepts, developing a selection of re-usable learning objects for different age groups. Resources include worksheets, presentations and interactive animations, which present scientific concepts in novel and highly visual formats. These were designed by members of CELS team. They range from interactive flash tools for undergraduates - the mole calculator (Figure 1) and dilution factor tool, to 'gravity balls' for primary schools. There is a 'molecular geometry' resource for students to support those with diverse entry profiles. There are also examples of teacher's tools and worksheets to help in production of lesson starter/closer activities.

outcomes and hence impact would be longer term embedded changes in practice such as adoption of e-learning, engagement with outreach or successful promotions.

\section{Investing in innovative learning}

a) TIPS TOPS projects

Some examples of themes and project areas are given below:

- Context-Based Learning - e.g. Forensic Skills Development in Criminalistics Practical Work;

- E-learning projects - e.g. Masters modules in Molecular Biology, e-learning resources for Protein Purification; Genomic and post-genomic investigation of micro-organisms;

- New approaches to practical work - e.g. Year 1 organic practicals with pre-labs; Learning materials to support practical skills in biological sciences

- Assessment - e.g. Assessment of large groups; Use of automated assignment marking systems in grading essays:

- Outreach - e.g. 'Physics for Forensics' Outreach Competition; Promoting and Developing Green Chemistry for schools and teachers and Ronnie the Skateboarder (Year 9 physics);

The curriculum focused materials are available for use in the classroom or for independent study at home and are available via the CELS website. Is your area of learning crying out for an interactive tool? Get in touch and we'll see what is possible.

d) Electronic voting systems (EVS)

The use of EVS was piloted in CELS during 2007, having been introduced to their potential by Simon Bates ${ }^{9}$. This led to a lot of interest in their use for formative assessment and checking conceptual understanding. We have since used EVS to look at threshold concept with first year physics students, in addition to using them widely in outreach activities with schoo children from 5 years old upwards. This happened in paralle with the study by Niyadurpola and Read ${ }^{10}$. We note, as they did, that EVS offer anonymity to the voter and so encourage participation in quizzes and evaluation. EVS also attracted much interest from European colleagues at sessions on the work of CELS ${ }^{11}$. 
Investing in raising aspirations - innovation in Outreach Fifty percent of our activity is Outreach based. When CELS started 'footfalls' of young people were around 2500 per year for science based activities, (mostly in chemistry) of which 1200 came from one big primary event. Since autumn 2005, we have significantly diversified both type and subject coverage of activity. Average footfalls annually are now around 5000 per annum and so far over 21,000 young people have experienced challenging and exciting science activities since CELS began its operations. Our evaluations show that an impact on learning and aspirations:

'Thanks to your contribution the students now have a renewed sense of not only the career opportunities throughout the science industry, but also that science moves outside the classroom' (Charlie Astbury, Northamptonshire Education Business Link Organisation)

Examples of types of outreach activity developed include: Activity Days; Competitions; Guest lecturers; Teacher CPD; Workshops; Master classes; Careers events; Kit in a Kase and Demonstration lectures. To see these in action visit our picture gallery on the outreach section of our website.

However, it's not just footfalls that matter, but the effectiveness of the learning experience. We have turned from large scale events with 500 pupils per day - where the extent of learning taking place was difficult to measure - to workshop based activities with smaller groups and adding teacher CPD activities.

'Not only do the schools appreciate the ability of the CELS team to go out into schools to deliver a varied menu of sessions but value the opportunity for them to take their children to a building like CELS on a University Campus and be able to see, handle and experience fully functioning laboratories. Such an introduction to the world of Science and University life at such an early age is bound to have an influence on the lives of some of our young people that will remain with them for a long time and maybe influence their career path and/or their desire to actually go to university later in life.' (Alan Carr, Manager of Education Improvement Partnership.)

a) Innovative Outreach through Kit in a Kase - activities in the classroom

CELS has piloted and developed new approaches to Outreach. The most successful of which is Kit in a Kase, a concept that was developed since the receipt of funding. These curriculum-focused, classroom-delivered activities involve presentations and hands-on practical activities, many of which are enquiry-based. Through working with $\mathrm{Dr}$ Sam Tang, from the University of Nottingham, we gained experience of her primary focused Oil spill activity which we co-delivered to regional audiences. This activity encouraged CELS staff to develop further activities for wider age groups, which we call Kit-in-a-Kase. Kits now range from early years infants - Materials Kit (KS1) and The Body (early KS2) to Bricks Bananas \& You (DNA) and Colour Chemistry. They have been delivered by a wide range of people - CELS staff, Students in Classrooms students, undergraduate and postgraduate student volunteers. Details are on the CELS web site and have been presented at a number of conferences ${ }^{12}$.
The overall Kit in a Kase scheme has proved so popular with schools that we are invited back to a school on many occasions. Teacher evaluations state:

'Links with real life are extremely valuable.' 'Explanation \& visual representation of a complex concept - how DNA relates to cells \& Biology.' 'Allowed kids to see role models \& ask questions one to one.' 'Whole session was excellent, Kids really enjoyed it - well organised and resourced.' 'Highly relevant to syllabus - Yr6 SATS is tough but this made physics element fun.' 'Facts in talk useful - show how chemistry is used in nature and history etc'

\section{b) Teacher CPD}

Many schools struggle to allow staff to attend off-site training, so CELS has developed another way to offer CPD.

Competition events, where schools bring teams of 4 pupils and a teacher, allow us to offer teacher CPD sessions, whilst their pupils are competing. These sessions include showcasing materials, updates on the latest $\mathrm{HE}$ research and equipment, as well demonstrations and activities that can be done in the classrooms.

In addition, CELS is working with the School of Education to provide additional opportunities for student teachers to develop their skills. There are sessions on advancing ICT skills, using data-logging equipment and interactive whiteboards. Student teachers have also attended interactive lectures from CELS on exciting and interesting experiments; these are based on the Royal Society of Chemistry (RSC) report "Surely That's Banned!?!" CELS has also worked with the Royal Statistical Society Centre for Statistical Education (RSSCSE) on their Experiments At School website and helping to run workshops for mathematics Enhanced Post Graduate Certificate of Education (EPGCE) students. [NB these are students on two year teacher training programmes funded by the government (TDA) with the first year involves Subject Knowledge Enhancement in key areas such as chemistry, physics, maths and modern languages.]

\section{Investing in learning spaces}

a) The CELS building

CETL funding brought with it significant capital funding (up to $£ 2.35$ million) which at NTU we used to co-construct a new building which houses the core of a science education development centre, alongside modern research labs. The CELS area consists of space designed by us to support the delivery of our key aims with a lecture theatre, 3 seminar rooms, an IT suite, a school lab ( allow development and delivery of practical activities to under 16s), office space for CELS team and seconded staff, meeting and exhibition space. These flexible modern facilities are seen as having a very positive impact on the wider community both internally and externally. CELS is used extensively for external facing events with schools, small scale HE conferences (e.g. events organised with the Physical Sciences Subject Centre) and professional bodies. There was very positive feedback from prospective students on University Open Days. It has extended the range of learning experiences with final year shows, poster shows, demonstration lectures, seminars, IT sessions and student society events. 


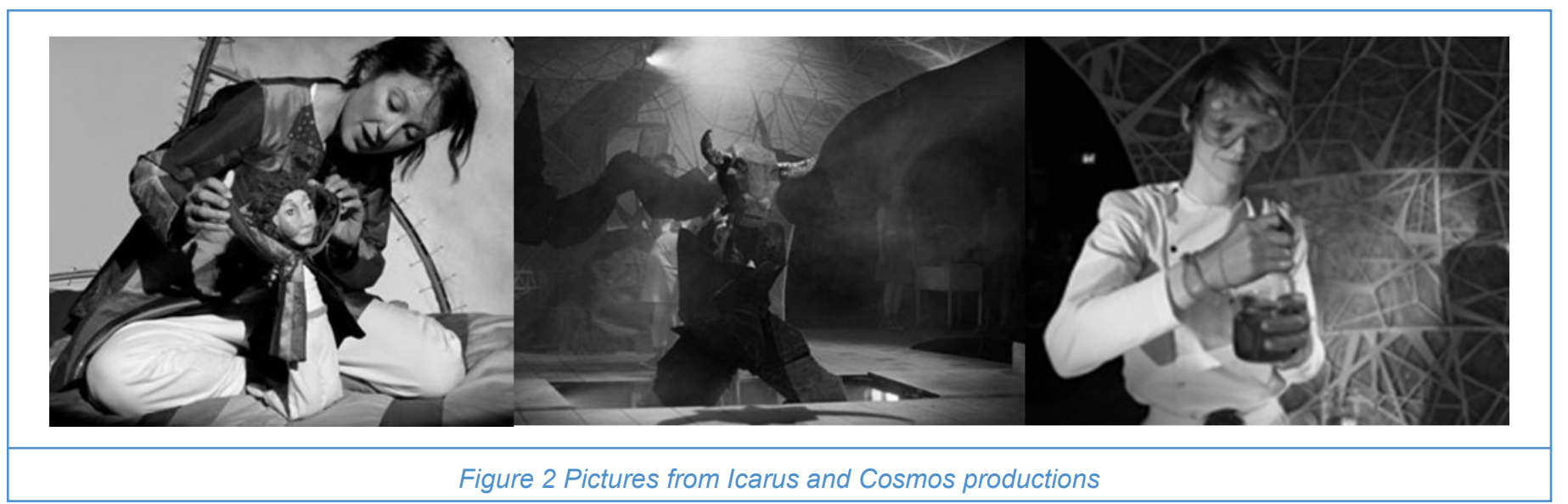

b) The Trent Observatory

One of our star achievements was being able to build and equip an observatory with $0.5 \mathrm{~m}$ telescope to support undergraduate programmes and provide opportunities for schools and members of the local community to learn more about the science of astronomy. Our monthly Open Dome Events are open to staff and the general public, with talks on interesting, recent and sometimes surprising topics relating to astronomy with opportunities to observe. We have developed a range of undergraduate projects and school based outreach projects that aim to introduce and encourage understanding of astronomy. Successful projects include: Distances in astronomy; Stars and their spectra; Meteors and craters; and Solar prominences and scale.

A very exciting innovation is a project on Archeoastronomy (what people in history understood about the stars and the part they played in their culture) with gifted and talented pupils at a local school. The students presented their work to the Joint European and National Astronomy Meeting (JENAM), as part of the European week of Astronomy and Space Science and International Year of Astronomy 2009 in April 2009. The project is led by astronomer and observatory officer Daniel Brown. The pupils had a great time, you can see their report at Astronomy Now! and on the CBBC's Newsround site ${ }^{13}$.

\section{Investing in Innovation and Creativity}

CETL funding has opened up opportunities to step outside our comfort zone and work proactively across the University. For example, we have worked with a resident theatre company Dragon Breath (see website) in creating ICARUS - an art and science performance event, aimed at engaging young people with the critical, moral and ethical issues of biomedical research. ICARUS takes the ancient Greek myth of Icarus and weaves it with a modern story about a research scientist desperate to save the life of her daughter who has a degenerative disease. Performed as part of the University's celebration of National Science and Engineering Week in March 2007, it involved a top team of professional theatre makers, working alongside undergraduates on theatre design programmes including puppeteers, designers and makers. Over two years professional artists, students, school pupils, teachers, CELS and scientists researched and developed the performance, which sold out to schools across the region. ICARUS was shortlisted for a THES award in Excellence and Innovation in the Arts. (Figure 2)
Building on this successful partnership our second project is COSMOS - following the story of a young girl who needs to travel through the solar system to retrieve her 'story star' after it disappears. On the way she meets all the planets, personified to display their characteristics, before eventually finding her dying star. Coinciding with the International Year of Astronomy and National Science and Engineering Week 2009, it was performed to four to seven-year-olds this March and May and is the result of 18 months' research and development by artists, scientists, teachers, students and pupils. These performances are participatory using storytelling, dance, puppetry, music and digital arts to introduce youngsters to some of the biggest scientific questions.

The children will be learning about the structure of our solar system, including distances and relations of size, as well as the life and death cycle of a star. Many of these children will be going to school for the first time, so the performance is also about them encountering new experiences and challenges and taking their place in the world. Another important idea is to show youngsters the importance of engaging with and helping others." Peter Rumney, Senior Lecturer in Theatre Design at NTU, Artistic Director, Dragon Breath Theatre.

CELS role has included helping theatre students understand the science behind the production, engaging fellow scientists, and supplying science advice as well as sponsoring resource packs for schools to follow-up on the science involved in the production.

\section{Working Collaboratively}

There has been a high degree of engagement of CELS with networks and local, regional and national initiatives. This has been one of the strengths of CELS -working in partnership has enabled us to achieve a wider variety of activity. The range of partnerships and collaborators can be found on the CELS web site and includes professional bodies, STEMPOINT,

Aimhigher etc. We have also built links with Schools in the Midlands region through active involvement in local initiatives, eg Nottingham Science City and the East Midlands STEM partnership.

Collaboration in outreach work has been a major characteristic of the CELS approach, demonstrated at two national CELS events on this theme Outreach in Collaboration (October 2006) and Outreach in Collaboration II (September 2008) (figure 3) . 


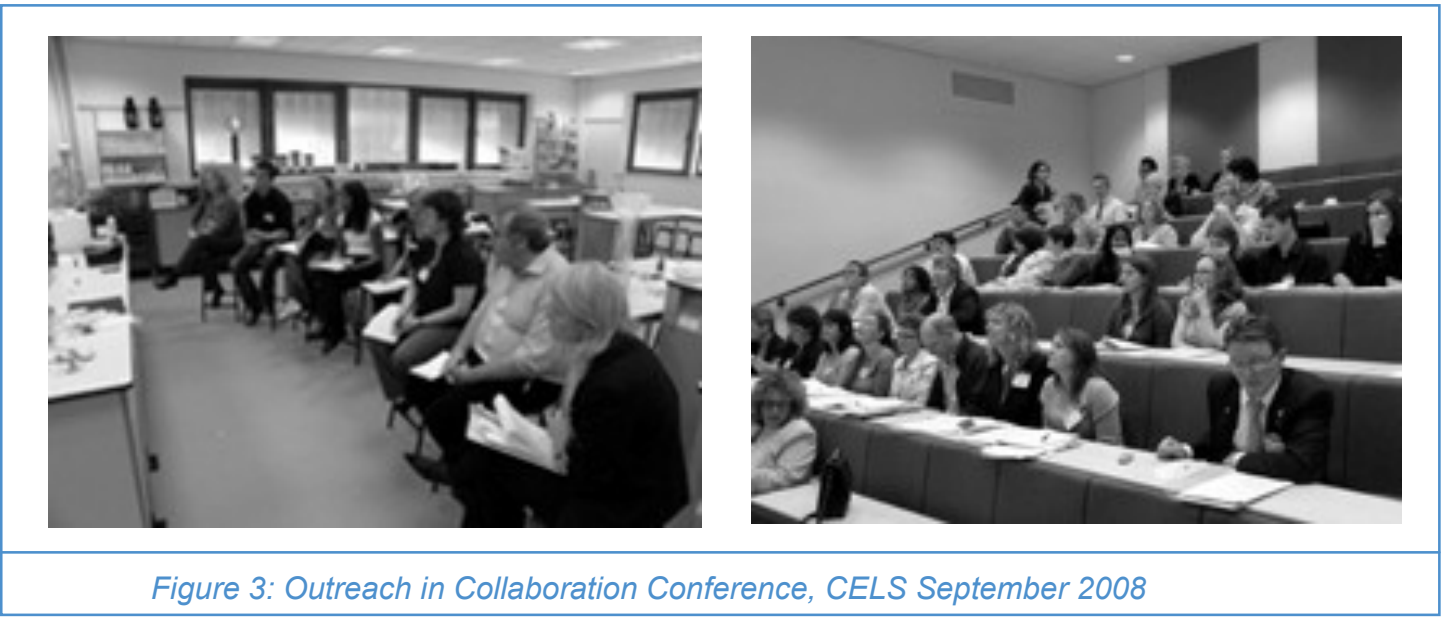

Other examples of collaborative working and dissemination are:

- Partnership of CELS with the HEA Subject Centres - with whom we have organised events, sponsored conferences, disseminated newsletters and support our CELS Advisory Group;

- East Midlands CETL network - joint events and outreach sessions.

- Chemistry for our Future- a multi-university curriculum development project ${ }^{14}$ and Chemistry the Next Generation events

- Stimulating Physics - hosting a Physics teacher fellow and their research project ${ }^{15}$.

- European partnerships - EUSCEA - contributing to science weeks \& festivals in Norway, Portugal and Italy as well as European funding.

Finally...

CELS has been characterised by its experimental nature. It's a tale of how scientists, educators and their students are being given time and space to implement HEFCE's vision that CETLs be innovative and adventurous in its approaches to learning and teaching. Through working in new areas in different ways with a very diverse group of people, we have learnt a lot about what works and what doesn't and we hope that by sharing these lessons with other members of the science higher education community that everyone will benefit.

If you would like to know more about any of our projects or approaches, then please get in touch or visit our website.

\section{Acknowledgements:}

This work was funded by HEFCE Centres for Excellence in Teaching and Learning (CETL) initiative.

\section{References}

1. McNeil, J, Meredith, A, Moss, K. (2008), HEA Annual Conference 2008 Vehicles for change: developmental schemes, their impact and implications , 1-3 July 2008, Harrogate, Higher Education Academy
2. Manning, G. and Moss, K. (2009) Getting the bug in schools, Microbiology Today, May 2009, p110-112; Manning, G. and Moss, K. (2009) Practical Skills in Biology - Engaging Your Future Market, Centre for Bioscience bulletin, No. 26, Spring 2009, p8

3. Roget's li. (1995) The New Thesaurus, [online] Third Edition. Houghton Mifflin Company. Available at <www.answers.com/topic/impact>

[Accessed 2 ${ }^{\text {nd }}$ April 2008].

4. Mcgraw-Hill. (2005) Encyclopaedia Of Science And Technology [online] The McGraw-Hill Companies, Inc., 2005. Available at

<www.answers.com/topic/impact>

[Accessed $2^{\text {nd }}$ April 2008];

5. Wainwright, S.(2002) Measuring Impact - A Guide To Resources,[online] National Council for Voluntary Organisations, 2005-7. Available <portals.wi.wur.nl/files/docs/ppme/ measuringlmpact20012003.pdf>

[Accessed 14th August 2009]

\& The UK Voluntary Sector Research Group. (2003)

Case-studies of impact assessment in small and mediumsized voluntary organisations Available $<w w w . n c v o-v o l . o r g . u k / a s p / u p l o a d s / u p l o a d e d f i l e s / 1 / 456 /$ measuringimpactreport.pdf $>$ [Accessed 2nd June 2009].

6. Moss, K. (2008) Impact - What is it \& does it matter? Paper presented at the Annual CETL conference, Leicester University, April 2008; and What is Impact and what does it mean for your CETL? Invited workshop, Middlesex University, June 2008

7. Nef.(2004) Measuring Social Impact,[online] SROI primer. Available at

<sroi.london.edu/Measuring-Social-Impact.pdf> [Accessed $2^{\text {nd }}$ June 2009].

8. Moss, K. Greenall, C., Rockcliffe, A., Crowley, M., Mealing, A. (2007) Threshold Concepts, misconceptions and common issues, Proceedings of The Science Learning and Teaching Conference 2007, p190-196; Moss, K. Greenall, C., Rockcliffe, A.(2007) Threshold Concepts, troublesome knowledge and knowledge gaps, Poster in , Proceedings of The Science Learning and Teaching Conference 2007, p280-281;

Moss, K. Greenall, C., Rockcliffe, A., Crowley, M., Mealing, A., Threshold Concepts and Troublesome Knowledge in Chemistry paper presented at Variety in Chemistry Education 2007, University of Leicester; 
9. Bates, S.P. and Howie, K. (2006) The use of electronic voting systems in large group lectures: challenges and opportunities, New Directions in the Teaching of Physical Sciences, 2, 1-8;

10. Niyadurupola, G. and Read, D. (2008) The use of electronic voting systems to engage students in outreach activities New Directions in the Teaching of Physical Sciences, 4, 27-29;

11. Moss, K. and Crowley, M. (2009) Communicating Science - CELS style! \& Electronic voting systems workshop to Norwegian Science Week Planning Conference, Norwegian Research Council, Oxford, March 2009; Moss, K. and Crowley, M. (2009) Threshold Concepts, Troublesome Knowledge and Effective Learning in Science \& Electronic voting systems invited presentation to Swedish Chemistry Teachers Conference, Swedish Chemical Society, Sigtuna, Sweden, March 2009

12. Westbrook, G. (2007) Kit in a Kase: versatile science activities for all in Proceedings of The Science Learning and Teaching Conference 2007[P37], ISBN 978-1905788-39-2. p295-6;

Westbrook, G., Moss, K., Mealing, A., Tang, S., Kit in a Kase: Outreach Activities for All workshop presented at Variety in Chemistry Education 2007 Beaumont Hall, University of Leicester, September 2007

13. Astronomy Now (2009) Mini brainiacs captivate conference audience published on-line at $<$ www.astronomynow.com/nam09/2009/04/mini-brainiacs -captivate-conference-audience.html>

[Accessed 1st June 2009]

BBC, (2009) We met the world's top astronomers! Published on line at <news.bbc.co.uk/cbbcnews/hi/newsid_8010000/ newsid_8014100/8014158.stm> [Accessed 1st June 2009]

14. Martin, P. and Moss, K (2008) The shape of chemistry in 2008, Paper presented at Physics Higher Education Conference 2008, University of Edinburgh, September 2008

15. Knowles, J. and Moss, K.(2008) Student Attitudes to Physics at School and University, Paper presented at Variety in Chemistry Education 2008, Dublin City University, September 2008

\section{There has been a high degree of engagement of CELS with networks and local, regional and national initiatives. This has been one of the strengths of CELS - working in partnership has enabled us to achieve a wider variety of activity.}

\section{Web Links}

CELS

$<w w w . n t u . a c . u k / c e l s>$

Kit-in-a-Kase

$<$ www.ntu.ac.uk/cels/outreach/Kits/index.html>

The Trent Observatory

$<w w w . n t u . a c . u k / c e l s / o u t r e a c h / O p t i c a l \_o b s e r v a t o r y /$

index.html>

Dragon Breath Theatre company

$<$ www.dragonbreaththeatre.com/>

Science City, Nottingham

$<w w w . s c i e n c e-c i t y . c o . u k />$

East Midlands STEM partnership

$<$ www.emstempartnership.org.uk/>

European Science Events Association (EUSCEA)

$<$ www.euscea.org>

Undergraduate Ambassadors Scheme (UAS)

$<w w w . u a s . a c . u k>$ 